\title{
Internationalisation of R\&D into Emerging Markets: Fiat's R\&D in Brazil, Turkey and India ${ }^{1}$
}

\author{
Suma Athreye ${ }^{2}$, Asli Tuncay-Celikel ${ }^{3}$, Vandana Ujjual ${ }^{4}$
}

Corresponding Author:

Vandana Ujjual (PhD)

SPRU (Science and Technology Policy Research)

Jubilee Building, Room 345

University of Sussex

Falmer, Brighton, UK

BN1 9SL

Email : v.ujjual@sussex.ac.uk

T el : $+44(0) 1273877262$

Fax : +44 (0)1273 685865

\footnotetext{
1 The research reported in this paper received funding from the European Union's Seventh Framework Programme under grant agreement $\mathrm{n}^{\circ} 225368$ (INGINEUS, Impact of Networks, Globalisation, and their Interaction with EU Strategies).

2 Brunel University, UK, Email: Suma.Athreye@brunel.ac.uk

${ }^{3}$ Isik University, Turkey, Email: atuncay@isikun.edu.tr

${ }^{4}$ SPRU, University of Sussex, UK, Email: v.ujjual@sussex.ac.uk.
} 


\title{
Internationalisation of R\&D into Emerging Markets: Fiat's R\&D in Brazil, Turkey and India
}

\begin{abstract}
:
The idea that competence creating subsidiaries from emerging nations can contribute to and possibly renew sources of competitive advantage is an appealing one for managerial practice and policy. Many mature MNEs can look to exploit the technological and market capabilities of their more capable subsidiaries in order to tap into new sources of growth. Based on a case study of Fiat and three of its emerging market R\&D subsidiaries we show that successfully developing competence-creating subsidiaries is a difficult task. Not only do parent and subsidiary managements have different ideas of what is involved but subsidiary technological capability and local resources do not fully explain new technology creation mandates. The success of overall product market strategies and the mode of entry also exercise important effects. Furthermore in our case study we find that internal embeddedness is more crucial than external embeddedness in distinguishing a successful new technology creation mandate.
\end{abstract}




\section{Internationalisation of R\&D into Emerging Markets: Fiat's R\&D in Brazil, Turkey and India}

\section{Introduction}

In the late 1990s the rapid internationalisation of research and development (R\&D) by many multinational enterprises (MNEs) into emerging markets, led to speculation amongst scholars about whether this constituted a novel trend capable of shifting MNE innovation into new regions. It is fair to say that there are as many pessimistic as optimistic views of this phenomenon. The pessimists caution that internationalisation of $R \& D$ has never involved very significant volumes of innovative activity and even in 2010, Patel (2011) showed that the larger volumes of technological knowledge typically are generated in the home countries of MNEs and in the home country's strongest technological fields (Patel and Pavitt, 1991; Verspagen and Schoenmaker, 2004; Patel, 2011). This strand of research points to the domination of this centripetal tendency because orchestrating global innovation can be both risky and complex to manage. Different and less adequate institutional features of new locations to support innovation activities make the geographic dispersion of $R \& D$ risky. The uncertainty of $R \& D$ outcomes and the need to conform to product market imperatives make MNEs' R\&D decisions both more complex and highly 'mission critical'. As a result, most 'significant' R\&D tends to be centralised in the parent company with the result that competence creation occurs there rather than in host locations.

The optimists believe that the dispersion of $R \& D$ facilities reflects a desire to find and exploit new markets through adaptive innovation, and to tap into new sources of technological knowledge and competitive advantage in a globalised world (Cantwell, 1995). They point out that there are huge rewards for the effective management of competence creating subsidiaries in geographically dispersed locations. The MNE can emerge as a hydra-headed organisation whose various branches in different geographical locations can exploit as well as renew competitive advantage through the internationalisation of R\&D (Kuemmerle, 1997; Cantwell and Mudambi, 2005). There is a rich literature on competence creating subsidiaries and their characteristics, which range from the dual embeddedness of subsidiaries in the local environment and in the MNE network of parent and affiliates (Almeida and Phene, 2004; Meyer et al., 2011); drivers of subsidiary roles (Bartlett and Ghoshal, 1991); to identifying mechanisms that can change 
subsidiary roles (Birkinshaw and Hood, 1998); and organisational innovation enabled by the participation of capable subsidiaries (Gerybadze and Reger, 1999; Lahiri, 2010).

The idea that competence creating subsidiaries from emerging nations can contribute to and possibly renew sources of competitive advantage is appealing for managerial practice and policy related to international investment. Many mature MNEs (such as those in Europe) can expect to exploit the technological and market capabilities of their more capable subsidiaries in order to tap into new sources of growth especially in the new phase of globalisation that began in the 1990s and which has encompassed several emerging markets. However, as the introduction to this Special Issue, and other papers in this volume make clear, we still have much to learn about the process of building competence creating subsidiaries, and the managerial and other challenges involved in creating technological advantages for firms from their subsidiaries in different geographical locations. Our paper makes a contribution to a better understanding of the barriers and enablers of competence-creation and new technological development in emerging market locations.

We focus on a European MNE (Fiat) in the automobile sector -- one of the first sectors to internationalise R\&D (Dicken, 2003; Manning et al., 2009). Fiat's 'selective globalisation strategy', adopted in the mid-1990s, shifted some of its R\&D out of Europe into emerging markets such as Turkey, Brazil and India. Using a case-study approach we study both the headquarters (HQ) R\&D centre and affiliate $R \& D$ centres in emerging markets to shed light on the constraints and managerial challenges involved in managing competence creating subsidiaries in emerging markets and the constraints to new technology development from these subsidiaries.

\section{Literature Review}

\section{1: Roles of Headquarters and Subsidiary}

Early understanding about the functioning of MNEs was linked to the product life cycle (Vernon, 1966) and internationalization process (Johanson and Vahlne, 1977) models. In both models, the MNE HQ has a dominant role and the MNE's foreign subsidiaries are totally dependent on centralised knowledge creation undertaken primarily in HQ locations 
(Dunning, 1981; Patel and Pavitt, 1991). Subsidiaries were often mini-replicas of the parent and encompassed a range of functions such as production, sales and adaptive R\&D. From the mid-1980s, the push towards globalisation saw the replica model of subsidiary organisation retreat and MNEs began to reorganise by rationalising some activities (to avoid duplication) and by increasing specialisation of their production and R\&D activities (Narula and Dunning, 2010).

Kogut and Zander (2003) note that following entry to a country the MNEs' subsequent expansion in the host location was a result of successful acquisition and recombination of local knowledge. At the same time, international expansion changes the global knowledge available to the MNE and imbues its subsidiaries with more power resulting in a transformation of the MNE to become part of a network of subsidiaries characterised by cross-border transfers of learning. The importance to an MNE of the capabilities of its subsidiaries for the company's competitive advantage should not lead to the conclusion that all subsidiaries are equal or should be treated equally. In dismissing this notion as the 'UN model' of MNE governance, Bartlett and Ghoshal $(1986,1991)$ argue that the role of the subsidiary within the MNE network is determined by the level of the subsidiary's capability and the strategic importance of the local markets in which it operates.

Based on a study of subsidiaries of a number of MNEs, Bartlett and Ghoshal (1986) argue that large or technically important local markets are likely to be of strategic significance. A high-capability subsidiary operating in a market perceived as strategically important can achieve the role of strategic leader and command a greater share of MNE resources, but a high capability subsidiary operating in a market of very little strategic importance will continue to be a contributor and may see the resources it develops being applied in other parts of the group. Low-capability subsidiaries operating in strategically important markets may be like black holes, drawing in resources from the rest of the group, while lowcapability subsidiaries operating in markets of small strategic importance, have no access to critical information and scarce resources, and are considered implementers, as 'deliverers of the company's value-added' (Bartlett and Ghoshal, 1991: 100).

Contemporary models of MNEs that see the strategic role of subsidiaries in the creation of MNE specific advantage are referred to as heterarchical models (Hedlund, 1986) compared to the hierarchical models implied by the product life cycle and the internationalisation 
literature. In heterarchical models, it is acknowledged that although the HQ treats the subsidiaries as partners in value creation, there can be tension between the two sides - most notably over the control and distribution of MNE resources, the control of agendas for growth and the execution of corporate strategy. In hierarchical models, most tensions are around coordination and operational issues. Contemporary models of MNE, ironically, promise greater rewards from subsidiary activities and participation, but also predict greater tension between parent and subsidiary in the process. We can expect the same kinds of tensions to characterise MNEs keen to develop technological strength using competence creating subsidiaries.

\subsection{Characteristics of Competence Creating Subsidiaries}

Competence creating subsidiaries are subsidiaries set up to promote innovation rather than sales. Bartlett and Ghoshal (1991) and Rugman, Verbeke and Yuan (2011) suggest that the concept of subsidiary capability can relate to production, sales, innovation or administrative support, and provide examples of MNEs that define their subsidiaries in these terms. They argue also that local environments may have high strategic value due to the existence of a lead market (as discussed by Bartlett and Ghoshal 1986) or due to technology and other factors such as supplies of labour and natural resources. The endowments of local environments can be linked to a particular task or role or to particular combinations with the subsidiary's resources. Subsidiaries that are strategic leaders in innovation are able successfully to combine in-house capabilities with location specific assets; implementers earn revenue for the company by exploiting most MNE specific assets.

The importance of combinative capability in subsidiaries in the MNE internationalisation R\&D strategy has been studied widely. Kogut and Zander (1992) and Phene and Almedia (2008) show that sourcing and combinative capabilities have significant influence on the scale and quality of innovation, specifically, combinative capability enhances innovation in subsidiaries by diffusing knowledge within the firm and integrating knowledge from different sources. This idea resonates with the finding of 'dual embeddedness' of competence creating subsidiaries, which, in turn, is associated with their better innovative performance (Figueiredo, 2011; Meyer et al., 2011). Dual embeddedness refers to the development of knowledge-intensive linkages with specific internal and external actors simultaneously. 
Studies on the embeddedness of the subsidiary in different institutional and competitive contexts using a more sociological perspective of informal interpersonal ties have a long history (Uzzi 1996, 1997; Andersson 1996; Andersson, Forsgrem Holm, 2002). These earlier studies were not only about technological embeddedness but distinguished between technical, structural, and business embeddedness of subsidiaries. The major insight of these studies was to point out that embeddedness was very closely linked to differing competitive and institutional situations which in turn could be a source of competitive advantage for the parent firm. However, they also recognise that such competitive advantage needs the internal embeddedness of the subsidiary while local embeddedness may favour greater autonomy for the subsidiary.

The important point to underline is that while recent papers view dual embeddedness as favoring subsidiary innovativeness, a subsidiary does not need to be dual embedded to perform internal transfer or when only a one-way transfer of technology (e.g. from parent to subsidiary) is needed; internal embeddedness is enough for a subsidiary to accomplish this. The Mudambi et al paper in this volume also highlights this point in the context of reverse technology transfer. Dual embeddedness would however, benefit both subsidiary innovativeness and transfer by making three-way communication possible viz. from the parent to subsidiary, from the local context to the subsidiary and from the subsidiary to the parent.

The more recent literature on the geography of the MNE also qualifies that the leader or laggard status of the MNE in its sector will determine the extent of its local embeddedness. Clustering in locations may be detrimental to leading firms in industries who have more knowledge to spillover to rivals and so the strategic deterrence thesis posits that technology leaders are deterred from entering clusters for fear of knowledge outflows. (Cantwell and Santangelo 2002; Alcacer and Chung 2007). With rising industry concentration, this explanation may be reversed. Thus, Cantwell and Mudambi (2011) argue that in the presence of high knowledge stocks and industrial concentration, dominant firms can attract suppliers and customers far more strongly to their network and so shut out weaker firms from entering the same networks.

Demand-led factors are also important for enabling R\&D. Cantwell and Mudambi (2005) note that higher levels of local sales and demand provide a greater incentive for process 
improvements and allow differentiation which increases profit margins. This finding is supported by Quadros and Consoni (2009) in a study of European MNE subsidiaries in Brazil, which shows that the product development capabilities of foreign auto subsidiaries vary with increasing scale. This might be due to the development of specialised assets and Penrosian capabilities within subsidiaries as a consequence of expanded scale and better division of labour within the subsidiary.

Although successful competence creating subsidiaries appear to exhibit a virtuous cycle in which higher demand for products fuels technological capabilities, and dual embeddedness results in the transfer of new knowledge to other MNE affiliates, not much is known about the relative importance of each factor (demand factors, dual embeddedness and internal embeddedness) in determining competence creating roles in MNE subsidiaries. This is the area explored in this paper.

\subsection{Changes in subsidiary role}

Birkinshaw and Hood (1998) identify head office assignment, subsidiary capability and local environmental factors as factors determining the subsidiary's role. Although changes in any of these factors could result in a changed role for the subsidiary, Birkinshaw and Hood identify and emphasise two main mechanisms for charter change, viz. parent-directed investment, and subsidiary-driven initiatives, which could be described generally as being predominantly top-down and predominantly bottom up. Parent company-directed initiatives may enhance the subsidiary's role through increased investments, but such initiatives may be a response to decreased subsidiary capability. On the other hand, subsidiary lobbying could lead to an enhanced role for the subsidiary, which may be reinforced by a greater focus on mandated tasks, which may result in an upgrading of its capabilities.

Birkinshaw and Hood (1998) propose that contextual factors might influence which mechanism predominates. Parent-directed processes are likely to dominate in corporate environments characterised by poor intra-corporate competition for resources, strong centralisation of decision-making, ethnocentrism among management, strong government support for investments, and particularly good subsidiary track record. High quality parentsubsidiary links and an entrepreneurial orientation among subsidiary employees favour 
subsidiary-driven processes. The richness of the local context and the strategic impact of the location do not privilege either mechanism in particular.

In the context of R\&D subsidiaries, Kuemmerle (1997) distinguishes between home-base exploiting and home-base augmenting subsidiaries, and suggests that they are quite different functionally and organisationally. Using the headquarters vantage point, Kuemmerle (1997) argues that home-base augmenting subsidiaries are usually smaller sized, headed by star scientists, likely to have good links with basic science networks in the host country and to be more parent company directed and less evolutionary in their set-up. ${ }^{5}$ Home-base exploiting subsidiaries are likely to be larger companies, managed by people experienced in production management, with good links with production managers in sister companies. Home-base exploiting subsidiaries have good liaison with local customers and achieve greater levels of local embeddedness (Ambos, 2005).

Using the subsidiary point of view, Hood and Young (1982) and Pearce (1994) classify foreign $R \& D$ labs according to three distinct types based on their roles. The first type is R\&D Support Laboratories (SLs), whose main role is to adapt existing products and processes. The second type is Locally Integrated Laboratories (LILs), which work in close coordination with various other functions in the subsidiary's local environment in order to develop or customize products according to local needs and demand. The third type is Internationally Interdependent Laboratories (IILs), which are not systematically connected with the MNE's production units, and work with other interdependent networks across the globe, to identify and create new products and processes. Thus, SLs and LILs are oriented toward adaptation of existing products and their distribution in host markets, while IILs are fairly independent research units where novel research is conducted.

From the vantage point of subsidiaries, the evolution of roles in R\&D from SL, to LIL and IIL may involve a shift from competence exploitation to competence creation and may be subject to the processes and mechanisms identified by Birkinshaw and Hood (1998).

\section{Research Methodology}

\subsection{Research Design}

\footnotetext{
${ }^{5}$ None of the subsidiaries studied in our paper are home-base augmenting subsidiaries.
} 
We believe we can better explore the factors that influence the evolution of competence creating subsidiaries in emerging markets through a focus on multiple subsidiaries of a single firm. Thus, our research design allows us to study multiple R\&D locations in emerging markets, within a single MNE. This is akin to an embedded case study design, since it involves more than one sub-unit of analysis (Yin, 2003). We focus on Fiat Automotives, a European MNE in the automotive sector, and draw on data gathered through interviews with managers at the parent $R \& D$ centre and subsidiary $R \& D$ centres in three emerging markets - Turkey, Brazil and India.

Dicken (2003: 376) notes that 'although the automobile industry is undoubtedly a global industry, there is a good deal of variety in the specific corporate and competitive strategies adopted by the leading companies'. Thus, the transnational strategies of General Motors and Ford in the mid 1980s were triggered by the existence of protective barriers around major national markets as well as by the high costs of transporting assembled automobiles from the US, but the strategy of Japanese firms in the same period, was to establish major integrated production systems in three global regions (Asia, North America and Europe). Most European manufacturers with the exception of Germany's Volkswagen, engaged in more limited global expansion, although by 2000, European automobile production networks had changed as a result of the opening up of Eastern Europe.

Manning et al. (2009) note that automobile was one of the first sectors to offshore engineering and design in globally distributed locations. Waning demand in advanced western countries has moved the centre of gravity of the auto industry strongly towards emerging markets. Sturgeon et al. (2009) report that while global vehicle production more than doubled between 1975 and 2007, much of this growth can be attributed to Indian, Chinese, Brazilian, Mexican and few East European economies' markets. International auto manufacturers also set up plants in emerging markets to take advantage of value chain savings through cost reductions and more efficient component procurement practices.

Fiat is typical of a large European MNE with global R\&D and production. For the 1970s and much of 1980s Fiat followed a strategy of developing their cars Italy, which then were produced and adapted to local needs by national subsidiaries. Balcet and Enrietti (1999) and Dunford (2009) identify a strategic shift in Fiat's thinking in the mid-1990s in response 
to increasing competition and falling sales in Fiat's key West European markets. This involved moving into emerging markets (where substantial growth in small-car volumes was foreseen) within a strategy of 'selective globalisation'.

Fiat's R\&D investments in emerging markets, while specific to their strategic vision and competitive situation, nevertheless are quite representative of the forces thought to influence the internationalisation of $\mathrm{R} \& \mathrm{D}$ in the automotive sector. Fiat was not a pioneer or leader in the trend towards of internationalisation of $\mathrm{R} \& \mathrm{D}$, and when competitors adopted a similar course, Fiat was keen to adopt sector best practice. At the same time, the shift in strategy provided a natural experiment to study the emergence of competence creating roles in $\mathrm{R} \& \mathrm{D}$ subsidiaries.

\subsection{Sources of data for the case study}

\subsection{1: Interview data}

Empirical $^{6}$ material for the study was gathered from a series of interviews ( 15 in total, see Appendix 1) undertaken at Fiat R\&D facilities between July 2009 and August 2011.In addition to at the parent R\&D unit, Centero Ricerche Fiat (CRF), we interviewed R\&D mangers in subsidiaries in Turkey, Brazil and India. In Brazil face-to-face we interviewed senior managers at two subsidiaries (FIASA and FPT Brazil) located in Betim and Belo Horizonte. In India, the Head of R\&D and the VP of the Engineering and Design (E\&D) Centre, FIAL, in Pune, were interviewed. In Turkey, R\&D managers were interviewed at the Fiat joint venture (JV), Tofaş, in Bursa, and at two other R\&D facilities (Mekatro R\&D in Gebze and Platform R\&D in Bursa). Transcripts of the interviews were sent to respective interviewees for comment and validation.

The histories of the three emerging market subsidiaries vary (see Table 1). All started out as marketing subsidiaries, two as JVs with local partners. The R\&D function was added after the mid-1990s.

\subsubsection{Secondary data sources}

\footnotetext{
${ }^{6}$ Interview data were generated within the EC 7th Framework Programme (FP7) project Impact of Networks, Globalisation, and their Interaction with EU Strategies (INGINEUS). We thank INGINEUS partners for help with the interviews in Brazil and Italy. The full list of interviews is provided in Appendix 1.
} 
In order to contextualise and interpret our interview evidence we drew on data from a range of secondary sources including business press reports (e.g. the Economist), and secondary data on Fiat from academic studies. In order to assess subsidiary innovative capability we used Fiat Group's patent data published by the European Patent Office (EPO), US Patent and Trademark Office (USPTO), and the national patent offices in Turkey, India and Brazil.

Table 1: Fiat Affiliates in Emerging Markets which were interviewed

\begin{tabular}{|c|c|c|}
\hline Turkey & Brazil & India \\
\hline Tofaş & $\begin{array}{c}\text { Fiat Automotives } \\
\text { (FIASA) } \\
\text { Fiat Powertrain (FPT) }\end{array}$ & $\begin{array}{l}\text { Fiat India Automobiles } \\
\text { Ltd. (FIAL) }\end{array}$ \\
\hline $\begin{array}{l}\text { JV between Fiat and Koç } \\
\text { Holding, one of the earliest } \\
\text { Auto producers set up in } \\
1968 . \\
\text { R\&D Centre established in } \\
1994 \text { without the support of } \\
\text { the HQ and funded by Koç } \\
\text { Holdings and the Turkish } \\
\text { Government }\end{array}$ & $\begin{array}{l}\text { Wholly-owned } \\
\text { subsidiary and the first } \\
\text { MNE production plant in } \\
\text { Betim, in } 1974 \text {. } \\
\text { R\&D Centre established } \\
\text { (1996), benefited from } \\
\text { available local } \\
\text { government incentives }\end{array}$ & $\begin{array}{l}\text { JV between Fiat \& Tata } \\
\text { Motors, set up in } 2007 \\
\text { which replaced the } 1951 \\
\text { JV with Premier Auto } \\
\text { Ltd. } \\
\text { R\&D Centre established } \\
(2008)\end{array}$ \\
\hline
\end{tabular}

\section{Fiat's international R\&D}

The geographical distribution of Fiat car sales between 1991-2011 depicted in Figure 2 shows that Europe represented Fiat's largest market outside Italy up to the late 1990s, after which time Brazil and the Rest of the World became more important. ${ }^{7}$ Figure 3 depicts the geographical spread of Fiat's R\&D centres in two periods, showing that it mirrored its production spread. The majority of its $R \& D$ centres have traditionally been located in

\footnotetext{
${ }^{7}$ Fiat routes most of its production and sales in the MERCOSUR region, via Brazil.
} 
Europe, but NAFTA and regions outside Europe are seeing some increase in R\&D subsidiaries.

Balcett and Enriettti (1999) note two aims of the selective globalisation strategy adopted by Fiat: first to produce a 'global car', especially oriented to the needs of emerging markets in Eastern Europe, Latin America, Africa and Asia, based on the successful Brazilian experience, ${ }^{8}$ and second to achieve cost savings and realise efficiency gains based on modular production with a common floor plan, component commonality and five alternative bodies, representing technological division of activity among large subsidiaries. Thus, the development of component production capability in each subsidiary location was an important determinant of the location decisions related to production and (adaptive) R\&D.

Ciravegna (2005) outlines in some detail the organisational changes that selective globalisation involved for Fiat. Starting from an innovation network where Fiat directly controlled every subsidiary, the new strategy envisaged the organisation of subsidiary value chains. Some subsidiaries were identified as more important partners of the HQ for this effort, and were referred to as production poles or Tier 1 subsidiaries. Initially these were located in Brazil, Turkey, Poland and Argentina. At the time of our interviews in 2009, there were only two Tier 1 subsidiaries conducting significant volumes of R\&D viz. Brazil (which had absorbed the activities formerly performed by the Argentinean subsidiary) and Turkey. The Polish subsidiary was an important production pole, but performed little R\&D. In Bartlett and Ghoshal's (1986) framework and locally integrated labs in the Pearce (1994) Tier 1 subsidiaries seemed to play the role of 'strategic leaders'. The material and information exchange between the HQ and Tier 1 subsidiaries were expected to be more frequent and important, suggesting more internal embeddedness.

${ }^{8}$ Dunford (2009) reports that the 'global car' was a small car forecast to cost about $\$ 8,000$ (pre-tax). 
Figure 2: Geographical distribution of passenger car and light commercial vehicles sales (in thousands)

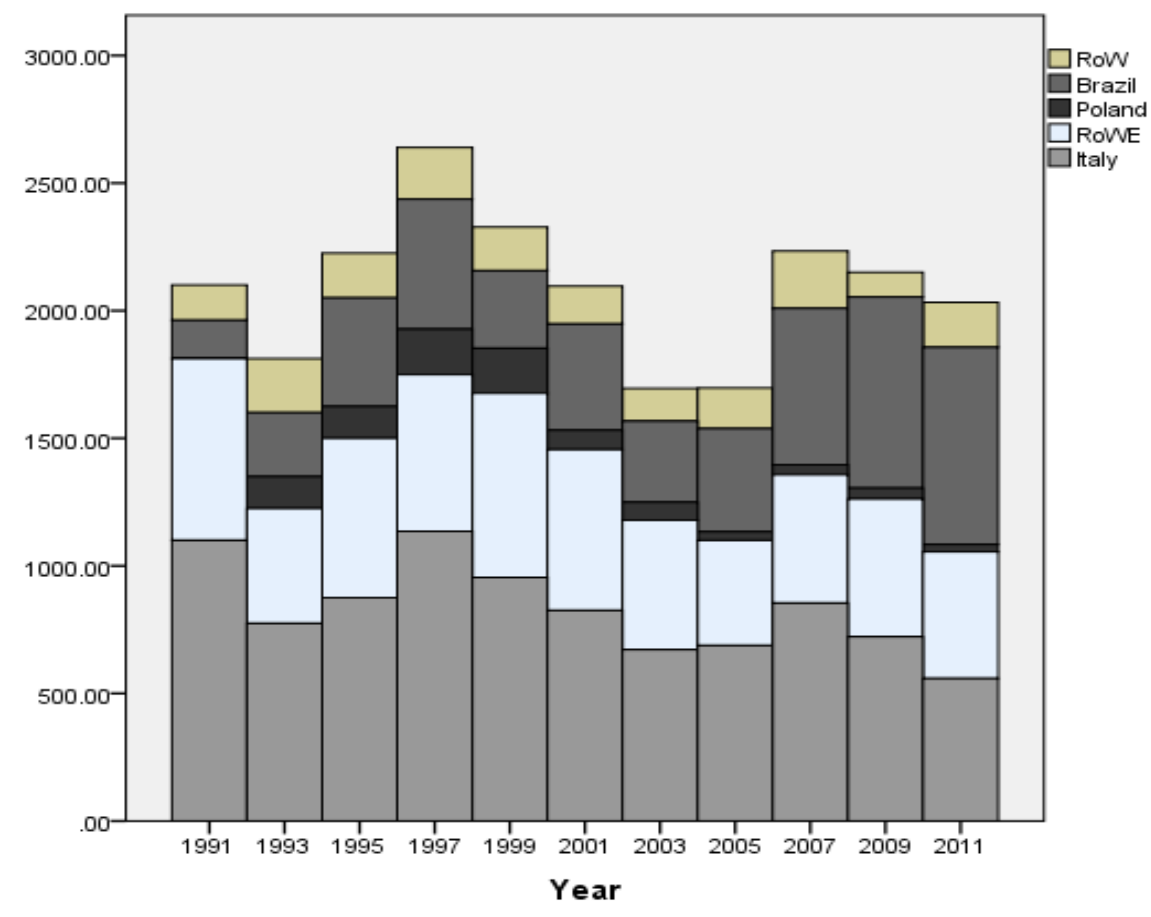

RoW- Rest of the World; RoWE- Rest of Western Europe; Sources: Fiat Group Annual Reports, Dunford (2009).

Figure 3: R\&D Centres distribution across the world regions

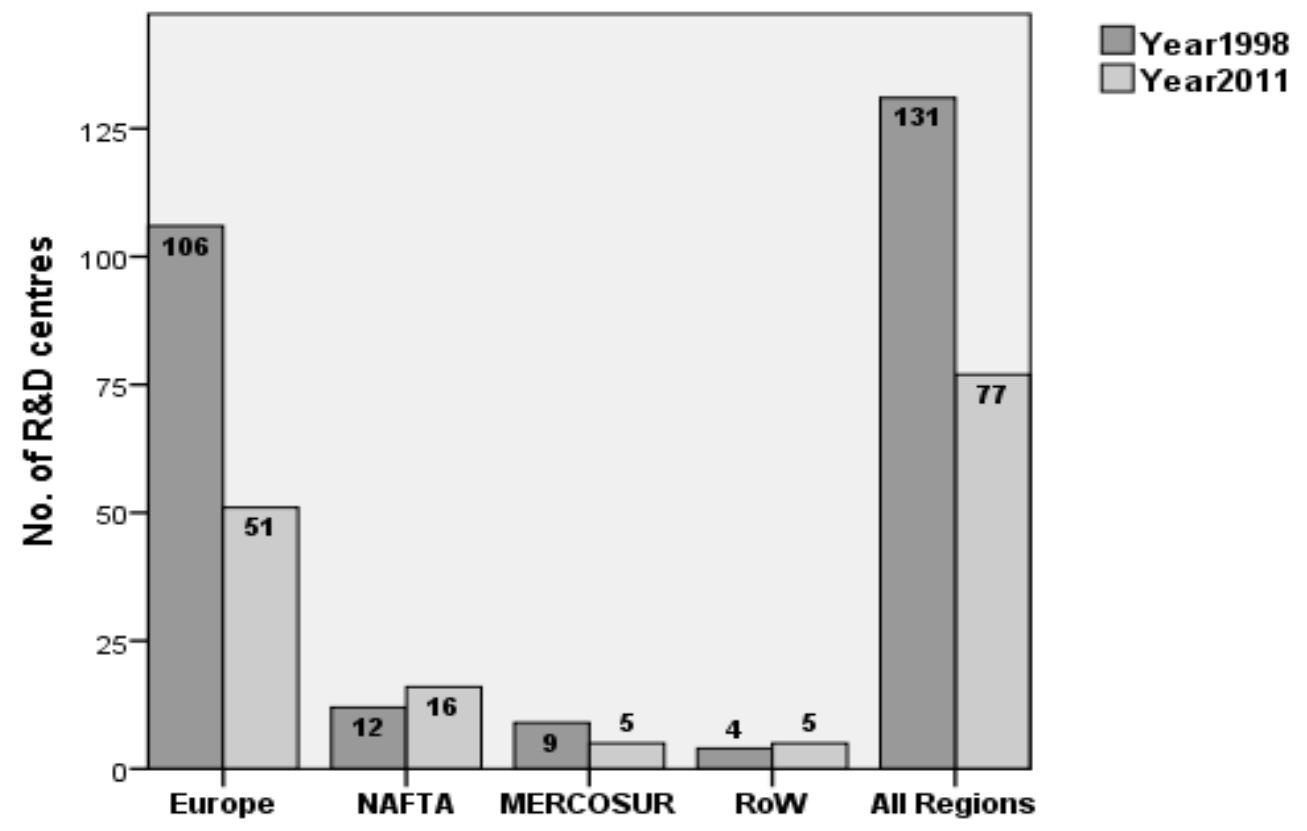

Europe includes EU 27 + EFTA (Liechtenstein, Iceland, Norway and Switzerland); NAFTA includes USA, Mexico and Canada; MERCOSUR includes Argentina, Brazil, Paraguay, Uruguay and Venezuela; ROW means Rest of the World.

Sources: Fiat Group Annual Report 1999; Fiat Group Annual Report 2011. 
There were significant information and material exchanges between Tier 1 and Tier 2 subsidiaries. These latter were located in India, China, Venezuela, Morocco, Egypt and South Africa and were envisaged as assembly plants. The reasoning was that compatibility and endogenous modularity of design and parts ensured production could be shifted among plants as relative prices changed, thus generating an element of competition among Fiat subsidiaries, and creating incentives for local managers to focus on continuous performance improvements. Production, sales, innovation and administrative functions were amalgamated in Tier 1 subsidiaries, but Tier 2 subsidiaries were not crucial for the execution of innovation-related tasks. The R\&D performed in Tier 2 firms was mainly related to adapting products to local requirements - e.g. fuel quality, road conditions, and policy regulations and requirements. In Bartlett and Ghoshal's (1986) framework they can be likened to contributors, and to support labs in Pearce's (1994) framework

In our interviews with $\mathrm{CRF}$, we asked how R\&D tasks were distributed between the home and other locations, in order to try to understand the factors that were important to HQ's assignment of subsidiary roles. We found their assignment to be fairly typical of firms that had been national champions in the 1990s - strategic R\&D performed in close interaction with the home country knowledge base, and relying on Italian universities and research institutes for basic research. One of our interviewees told us that :

In general, researchers and engineers in Italy develop core technologies and products which have global relevance and are later spread worldwide (common rail, multi-air, environmental friendly cars,). Local centres are generally focused on the customization of basic technologies on the specific needs of their market.

There are exceptions, of course, for example, basic R\&D in bio-fuels and diesel technology is performed in the Brazilian subsidiary.

There is centralisation of R\&D decision making, and a well-defined hierarchy of R\&D functions in different locations in Fiat. One advantage of such an arrangement is that it eases knowledge transfer within the MNE, and between production centres, since the knowledge crucial to a particular market was located there. An interviewee said that: 'In any case, it is not necessary to transfer all the information, but only those which are needed'. Another advantage of this strategy was that poor IP protection in the host location (a perennial problem in emerging economies) was less of an issue for the location of R\&D. 
The company patented its innovations. As local innovation was useful only in that particular market, the patent provided protection from local competition.

In response to questions about the evolution of subsidiary R\&D mandates, we were told that although different R\&D centres had different functions and had evolved differently, 'In general, the Group tries to avoid any duplication of functions, in order to reduce the waste of resources and increase effectiveness: this principle is always taken into account when a new centre is created or new activities are assigned'. Accordingly governance of international R\&D was the responsibility of a Central Committee that decided about which technologies to transfer and how - mostly achieved by a system of agreement and delegation. Local centres could propose new products, test their feasibility and request financial resources for experimentation and testing. Avoiding duplication of functions promoted technology collaboration among, which competed only for funding from HQ.

Researchers at the CRF considered two factors as important for driving international R\&D: closeness to the local markets, and the competencies and knowledge existing in the local country. This latter was contrary to expectations: we expected that it would be the local competence of the subsidiary that would to matter as suggested by Bartlett and Ghoshal (1986, 1991) and Birkinshaw and Hood (1998). Our interviews clarified that whilst the competence of the local subsidiary was important, 'the level and quality of local competencies depended also on the degree of collaboration with the universities and on the presence of a good education system, offering highly trained human resources'. Second order networks (described by one interviewee as 'networks of networks') are also considered important for location decisions although we were unable to elicit examples of a R\&D subsidiary being set up principally for this reason. Several interviewees told us that in many cases where Fiat has no direct contacts, existing networks with universities or other partners are exploited. This is consistent with Fiat's policy of partnering with established firms in Turkey and India and supports the view that innovation occurs in subsidiaries that are well embedded in the local milieu.

Fiat clearly sees collaboration as important for cutting the high costs of production and research. Although our main interest is in the internationalisation of $R \& D$ it should be noted that Fiat entered into many production collaborations with suppliers in order to reduce costs (Dunford, 2009). Collaborative activity is an important component of its R\&D 
internationalisation in Europe and, at the time of our interviews, Fiat had more than 1,500 partners in Europe (including universities, research centres and other firms) and had participated in about 560 European Commission funded research projects.

The main mechanism for exchanging technological information is exchanges of engineers between CRF in Turin and the subsidiary. Because its engineers use common design tools, Fiat has been successful in using virtual platforms and information and communication technologies (ICT) for knowledge transfer, confirmed by interviews with R\&D subsidiary managers. The effect was most pronounced in reduced time-to market: Fiat claims to have the shortest time-to-market (15 months) in the automotive sector. ${ }^{9}$ This was achieved because the design of both the Bravo and 500 models relied on computer simulations rather than prototypes (Economist, 2008).

\section{Fiat's R\&D subsidiaries in emerging markets}

Fiat's R\&D activities in emerging markets are market-driven and consist of adaptive R\&D to support their production subsidiaries in those regions. Product customization and intensified localisation of components and systems was required to respond to difficult road conditions and variations in fuel quality. Also, carbon emissions and safety regulations differed from those in developed markets. Some markets (e.g. Brazil, India) also had local content requirements for cars produced and sold locally.

Tofaş, Fiat's JV in Turkey, is its oldest emerging market R\&D centre (set up in 1994) followed by the wholly owned subsidiary in Brazil (set up in 1996). The Indian subsidiary was established in 2008, although a production JV with Premier Cars has been in place in India since 1951.

In two of the three emerging markets we study (Turkey and India) a JV was considered more practical for production and $R \& D$ than a wholly owned subsidiary. Joint venturing for R\&D is unusual since it introduces the risk of technology leakages and can result in loss of focus if one partner is not fully committed. As noted in Section 4, most R\&D decisions about tasks and apportioning of resources in Fiat are centralised. Birkinshaw and Hood

\footnotetext{
${ }^{9}$ The Economist (2008) reported that Fiat had cut its time to market from 26 to 18 months
} 
(1998) suggest that this type of corporate level structure favours parent-led investment and divestment of subsidiary roles, which is at odds with the partnership model implicit in a JV. These tensions may have influenced the evolution of roles in the Turkish and Indian subsidiaries.

The salient characteristics of the three emerging market subsidiaries we study are outlined in Table 2 below. The Brazilian subsidiary is clearly the most important overseas subsidiary and one of our interviewees noted that the second in command at Fiat had spent some time there, suggesting a stronger parent-subsidiary link. Brazil and especially Turkey have a large number of patents - the traditional measure of innovative capability. However, only the Brazilian subsidiary seems to collaborate on innovation with sister affiliates, suggesting greater co-invention and internal embeddedness. This suggests that the dual embedded subsidiary is selected on characteristics other than technology capability alone.

Table 2: Salient characteristics of Fiat's Emerging Market subsidiaries

\begin{tabular}{|c|c|c|c|}
\hline & Turkey & Brazil & India \\
\hline \multicolumn{4}{|c|}{ Innovation Inputs, 2010} \\
\hline R\&D spend & $€ 100$ million & $€ 270$ million & $€ 30$ million \\
\hline R\&D Staff & 391 & 857 & 80 \\
\hline Engineers $\%$ of total staff & $65 \%$ & $73 \%$ & $85 \%$ \\
\hline \multicolumn{4}{|c|}{ Education level of R\&D staff (count) } \\
\hline $\mathrm{PhD}$ & 5 & 9 & 0 \\
\hline Post Graduates & 67 & 197 & 28 \\
\hline Graduates & 184 & 423 & 40 \\
\hline Vocational & 135 & 228 & 12 \\
\hline \multicolumn{4}{|c|}{ Innovation Outputs (Count of patents filed), 2012} \\
\hline Total & 71 & 47 & 0 \\
\hline National patent office* & 38 & 37 & 0 \\
\hline$E P O^{\wedge}$ & 33 & 5 & 0 \\
\hline USPTO & 0 & 5 & 0 \\
\hline $\begin{array}{l}\text { Collaborative patents filed } \\
\text { involving HQ inventors }\end{array}$ & 0 & 0 & 0 \\
\hline $\begin{array}{l}\text { Collaborative patents with } \\
\text { other afiliates } \\
\text { Total }\end{array}$ & 0 & 5 & 0 \\
\hline
\end{tabular}




\section{European Patent Office}

US Patent Office

Sources: *Turkish patent institute http://www.tpe.gov.tr/portal/default.jsp; PATENTSCOPE, World Intellectual Property Organization (WIPO) http://patentscope.wipo.int/search/en/search.jsf; IP Intellectual Property India, http://www.ipindia.nic.in/. $\wedge$ EPO, http://worldwide.espacenet.com/?locale=en_EP

^^USPTO, http://appft1.uspto.gov/netahtml/PTO/search-bool.html;

\subsection{Turkey - Tofaş}

Tofaş is central to Fiat's global production strategy, one of whose aims was to supply the Russian market with production from Tofaş. The decision to conduct R\&D in Tofaş, however, was taken by Koç Holding, the other partner in the joint venture, presumably because some adaptive R\&D was necessary to respond to local needs and to increase local sales. This was an autonomous decision, enabled by the resources of the independent JV partner and subsidised by the Turkish State. In interview, the R\&D director of Tofass said:

In 1994 when we established the R\&D department, this met no enthusiasm at Fiat initially: Fiat's main goal was open production in Turkey, but there was no thought of involving Tofaş in Fiat's R\&D activities. On the other hand, we were very ambitious to start R\&D in Turkey. We definitely believed that establishing R\&D would not only enable us to improve our product quality, but it would also increase the added value in new models. Although our managers believed that we would be able to succeed in contributing to the R\&D activities of both; Fiat believed that forming $R \& D$ with a local partner would not make any substantial contribution. Thus, we took this decision alone, without asking Fiat. The first humble step was to establish an emissions laboratory, but subsequently Fiat recognized the benefit of this expansion and let us establish our own development team.

The perception of Tofaş's R\&D manger is that Fiat's recognition of the value of using the new $R \& D$ capability in Tofaş was forced by cost-considerations. Fiat recorded losses of $€ 4$ billion in 2001. The cost advantage R\&D hirings at Tofaş represented a 50\% saving on similar Italian engineering hires. ${ }^{10}$ In addition, since 2008 , according to Turkey’s R\&D Law, up to $30 \%$ of the R\&D projects of Tofaş were eligible for funding from the Turkish government. Since 1996, the Turkish government has funded 29 R\&D projects through the

\footnotetext{
${ }^{10}$ Interviewee's estimate for 2001.
} 
Scientific and Technology Research Council of Turkey (TÜBİTAK) Technology and Innovation Support Programmes (TEYDEB).

The first product development project, initially involving eight people and $€ 26.76$ million was the Liquid Petroleum Gas (LPG) Adaptation of the Murat 131 (the Tofaş model based on the Fiat 131). The R\&D department's mission was to react in a timely and efficient way to any production problems in order to increase quality and reduce costs, using existing technologies. Since then, R\&D capabilities at Tofaş have expended through production support (1994), process verification (2002), prototype production (2004), and new product development (2007). This is reflected in Tofaş's level of responsibility in Fiat's new development projects- in particular, they had responsibility for light vehicle production. This progress was sequential and is consistent with evolutionary development of MNEs described in Cantwell and Mudambi (2005); it was enabled by significant investment from the parent company and Koç Holdings.

Tofaş also established R\&D facilities in Turkey's premier institutes, enabling a high level of local embeddedness and networking with universities, scientific institutions and supplier firms. It intensified local $R \& D$ activities in order to access $R \& D$ incentives and funding for projects undertaken in Technology Free Zones and Parks. In 2010, Tofaş had involvement in 69 university and research institute projects, many of which were funded by the EC Framework programmes. ${ }^{11}$

Despite growing technological capability in the subsidiary and high level of embeddedness in the local context, research activity at Tofaş did not achieve significant levels of internal embeddedness. At the same time, our interview with the Chief R\&D officer at Fiat also confirmed that while Fiat valued the successful partnership implicit in a 40-year joint venture they had no plans to allow new technology creation within Tofaş.

Tofaş concentrates on light commercial vehicles. So far, it is not expected for Tofaş to make R\&D on new technologies, like intelligent vehicles, vehicle communication, fuel cell vehicles, electric and hybrid vehicles. In 2010, managers at Tofaş were also exploring plans for Tofaş to emerge as a R\&D services provider to other car-makers such as GM and Chrysler, for whom they already produced cars and prototypes following the economic liberalisation in 1996.

\footnotetext{
${ }^{11}$ Estimate given in interview.
} 


\section{2: Brazil - FIASA and FPT}

Fiat Brazil is Fiat's largest subsidiary in terms of employment, output, and R\&D expenditure (see Tables 2 and 3). The production plant was established in Betim, Minas Gerais, in 1974. Cassiolato et al. (2001) note the important role of government incentives in this location decision. The Development Centre (Pólo de Desenvolvimento Giovanni Agnelli - PDGA) was established in 1996 and focuses on specific research areas: conception and design in the Estilo Center, electronics, chassis and body in Project Engineering, experimentation, prototypes and materials engineering in Experimental Engineering. An important (and growing) area is materials engineering. Compared to Tofaş, the product development team at Fiat Brazil is extensive, comprising 850 workers in 2010, including 650 engineers dedicated to R\&D.

Fiat's entry in the Brazilian market in the 1970s occurred at a time when the Brazilian automotive sector was highly protected and subsidized through high tariffs, import substitution and domestic content requirements for foreign firms. Ciravegna (2003) argues that structural reforms in the 1990s pushed auto assemblers such as Fiat to undertake costly modernization investments in Brazil and Argentina. Quadros and Consoni (2009) note that this was primarily market seeking investment based on growing domestic demand in Brazil, and output doubling from 1 million units in 1991 to 2 million units in 1997. Between 1998 and 2005, however, domestic demand stagnated, but global assemblers, such as Fiat and GM, were able to enhance the product development capabilities of their local subsidiaries due to substantial growth in intra-regional exports driven by the creation of the MERCOSUR regional trading area.

Cassiolato et al. (2001) argue that the MERCOSUR automotive agreements were a catalyst for the gradual emergence of regionally integrated production chains in the area, and the closer integration of local production in the global value chains of assemblers such as Fiat. Fiat's integrated modular production system was developed in response to the opportunities offered by regional integration in MERCOSUR, although in accordance with a strategy of regional integration and globalization of production in Brazil, Fiat went beyond adaptation and re-engineering. It engaged in design of regional derivatives of its global platforms and developed local autonomous engineering centres capable of participating in global platform 
projects and to provide inputs related to local requirements and design regional derivatives to suit local preferences (Quadros and Consoni, 2009).

The global 'small car' targeted at emerging markets was born out of these strategic initiatives. Queiroz and Carvalho (1999) note that the cars designed for developing countries combine the features of sturdiness, simplicity and low cost within new technological designs. Fiat Brazil exported the Palio Weekend station wagon to Italy when Fiat did not produce a similar product. Fiat pursued upgrading through local R\&D by involving the Brazilian subsidiary in the design of its platforms aimed at emerging markets. An interviewee from Fiat Brazil told us: 'In the Brazil car market, Fiat has the highest market share. We are very proud of this. We are powerful in Brazil. We believe we make the best cars for the Brazilians' (emphasis added), implying a local rather than global outlook.

Over time, as Quadros and Queiroz (2001) show, integration of Argentinean and Brazilian operations eventually led to the Argentinean subsidiary's design activities going to Brazil. The strategic decision regarding the production of P178 models in Latin America was made by Fiat Brazil. New models based on the P178 platform have been developed entirely in Brazil. Quadros and Consoni (2009) note that while Fiat adopted a consistent and pioneering product policy by designing global cars for emerging markets, the technological effort that this policy required, until recently, was centred mainly in Italy (although with the participation of Brazilian engineers).

The role of HQ R\&D was confirmed by an interviewee

the Brazilian subsidiary has evolved from an early phase commonly called 'tropicalization', in which the technology is imported and adapted to local market tastes and conditions, to a phase in which several product engineering to define model, design and style are present. In the past 8 to 10 years there was a clear qualitative upgrade in terms of development, whereas the vast majority of high-end research is still carried out in Italy.

Strong ties between the two Fiat subsidiaries in Brazil, and interactions with external suppliers allowed more autonomous product development. The subsidiaries collaborated on several projects including development of the new Uno. The free flow of knowledge 
within this network was critical throughout its development. There were also frequent visits by local engineers to HQ. An interviewee at FIASA told us that: 'We are good at design. Because of the time differences we are mostly independent. We do not need to contact HQ on a routine daily basis but we have a lot of employee rotation'.

Apart from the joint project on bio-fuel technologies with the University of Mina Gerais, university links are used mainly to access lab facilities for testing. Universities also provided training programmes (seminars and automotive engineering courses) to enhance local skills. FPT Brazil participated in initiatives, such as new materials research for flexifuel engines. Its formal and informal interactions with suppliers were decisive in developing the flexi-fuel engine.

Our interviews show that the Brazilian subsidiary is competence creating and plays a significant role in Fiat's expansion strategy in relation to its largest market. It plays a leading role in defining Fiat's competitive advantage in other emerging markets. Fiat hopes to sell cars developed in Brazil to countries such as India and Venezuela. This enhanced role of Fiat Brazil has been based on a mix of parent driven investment and the subsidiary's ability to upgrade its technological capabilities to fulfil its mandate.

\subsection{India - FIAL}

The Engineering and Development Centre was set up in 2006 as a part of a larger JV between Tata Motors and Fiat which involved marketing of Fiat products, licensing of Fiat's engine technology to Tata Motors, and joint R\&D. At the time of writing this paper, the marketing element of this JV had been dissolved, although the R\&D component has not been formally closed. However, our study provides some understanding of the tensions and constraints involved in the internationalisation of $R \& D$ in a hypercompetitive market like India.

The Indian auto component industry saw a renaissance post-liberalisation ${ }^{12}$ and the FIAL venture is located in the Pune auto belt, which is densely populated with component

\footnotetext{
12 Kumaraswamy et al (2012) show the catch-up and integration of auto component firms from India over the 1992-2002 period. In particular they find that improved performance based initially on technology collaboration with MNEs gave rise to significant increases in own R\&D expenditures and saw the leading component firms integrate with major auto producers.
} 
suppliers serving three major Indian auto firms - Tata Motors, Bajaj Auto and Mahindra \& Mahindra (M\&M). Two of these three domestic firms have been successfully introducing cars based on cheap, but competent designs, which threatened a core capability of Fiat. ${ }^{13}$ The decision to locate in Pune may have reflected a desire to tap into cluster spillovers; however, found no direct evidence of this motivation from our interviews with $R \& D$ Managers at the Indian subsidiary.

From the FIAL Engineering and Development (E\&D) Manager's point of view, the JV with Tata was initiated mainly for cost-cutting:

Fiat earlier had a collaboration with Premier Inc. - in Kurla in Bombay- that did not work well. There was a commercial issue- spare parts were very expensive, it is coming from Italy, hence customers were not very happy with after sales. But the product was very good- product-wise the customer is very happy, even now. [They] decided to close down and join hands with Tata Motors because Tata Motors has got a very good network. That was what Fiat wanted to cash on --the spare parts and after- sales which is more valuable in this JV.

Reports in the business press suggest that the JV was an opportunistic response. Mishra and Surendar (2010) suggest that in 2005, Tata Motors needed to invest in an expensive engine development programme in order for its cars to compete and comply with new environmental rules. The Fiat-GM power-train, which combined high performance with fuel efficiency, was the best engine for small cars, ran on petrol or diesel, and avoided heavy investment by Tata. Fiat's previous collaboration in India had been losing market share consistently since the entry of Japanese auto manufacturer Suzuki (in 1981) through a JV with the public sector company Maruti, and continued to do so after liberalisation of the automobiles sector from 1991. Therefore, Fiat was looking for dealerships to maintain and grow its presence in India and Tata Motors was reputed to have the best sales and service network in the country.

A rather complex JV was set up around a production facility that would make Fiat cars and engines and would also produce Tata's Manza (sedan car). The JV would sell its

\footnotetext{
${ }^{13}$ M\&M introduced the Scorpio (a SUV vehicle) in 2006, conceptualized and designed by the in-house integrated design and manufacturing, team but using systems designed directly by suppliers. Scorpio won a number of awards. In 2008, Tata Motors introduced Nano - the world's cheapest car (\$2000) based on frugal engineering concepts, and this vehicle received many international awards for design and performance although it did not achieve the commercial success that Tata expected.
} 
production to Tata who would distribute the cars (Fiat and the Manza) through its dealerships. Tata Motors also agreed to buy a certain number of power train engines on payment of a royalty. There were other implicit aims. Tata probably hoped to use Fiat's network for their sales of the Tata Nano in Latin America, while Fiat probably expected Tata Motors to help it to source cheaper components from India.

R\&D managers at FIAL claimed localisation of component manufacture was the key to cost cutting. FIAL's manager noted that his target of locally sourcing $90 \%$ of the components within the first year of operation was the heaviest localisation requirement demand of any MNE for which he had worked. He added that:

Value Engineering and Value Addition (VAVE) were undertaken with localisation.

While we were doing localisation there was also design change and design modification done to adapt to the local requirements, (road condition, the way we drive, ECU calibration modification for our driving situation- we don't drive at high speed).

Other aspects of VAVE that highlighted by our interview were:

One is the feature, the 'decontentment' (Auto industry term for removing features from upcoming model years, usually to save money), one part which is visible. For example, the higher-end cars like Emotion are fully motorised, whereas Active is having motorised in front and manual behind. So the customer is able to see the difference and gets a feeling that I am paying less hence I am getting slightly less. That is one part. But more than that what is important is that customer does not know that he has got a slightly less cost without a compromise. That is more intelligent work.

We do a lot of VAVE workshops. Let us say, we will strip open a part and we will discuss each and every component about where we can save cost. This is one kind of exercise. I also strip open the competitor's, which is in the cars which is already sold so not infringing anyone's patents. So we strip open that and try and understand what is it that we can get benefit. It is easy to reduce the cost but at the same time one must know where you are compromising. .... This is one kind of exercise that is hugely done here. This is done with the knowledge of the HQ. Many times they also come and participate. 
We also do cost engineering exercise by breaking into the component details. Therefore if you ask me to evaluate a product I get into finer detail, each and every component such as what are the materials used, how much machining is done, what treatment is done on that etc.

Despite the requirement to reduce costs and tap into reverse engineering skills, it was clear that R\&D outlays ultimately depended on sales performance. Following initially positive beginnings both models introduced by Fiat ran into problems. Mishra and Surender (2010) note that the Punto was perceived in the Indian market as underpowered for its premium price, while the sedan Linea had air-conditioning problems that undermined its sales. In our interviews the R\&D manager was particularly irritated with Fiat HQ's approach to the airconditioning problems and the rigid procedures for changing design details. He told us that:

Europeans designed the air conditioning in our car and there was no issue earlier in Brazil or Europe, but in India we said that the AC won't work, the temperature in North India is $48 \mathrm{C}$. Even at 40 there is high humidity which requires a very strong AC system. Our car did not have a very strong AC system. We initially highlighted that there will be a problem but they did not realise that there will be a problem.

It is very natural that the HQ will be very comfortable if the foreign location has obedient people who can produce as per their design and direction, their job is to produce as per design and sell it. ... There was tremendous supervision as the Fiat HQ was not sure of Indian companies, and whether the engineers working here can do a good job.

These rigidities probably undermined Fiat's competitive position in the Indian small car market, which, following liberalisation, had become quite competitive, with both Volkswagen and Toyota making deep inroads into the market shares of Fiat and Tata Motors. Fiat subsequently blamed Tata Motors dealers for not investing sufficient effort in selling Fiat cars, and in 2010 established its own showrooms and took over management of Fiat sales. It announced that it would launch the Cinquecento in India in 2013.

Expansion of operations at FIAL was constrained by Fiat's choice of product, which threatened to undermine the size of its R\&D function in India. However, FIAL's manager 
was remained optimistic because he believed that, in time, India could become a hub for the manufacture of right hand drive cars and this would help the R\&D effort in India.

\section{Discussion}

Like several other companies in the automobiles sector, Fiat embarked on a strategy of globalization of production and $\mathrm{R} \& \mathrm{D}$ designed to cut costs and penetrate emerging markets. Its $R \& D$ in emerging markets was of the home technology exploiting type. The case study of Fiat and its three emerging host markets provides an understanding of some of the factors important to the development of competence creating subsidiaries in R\&D; we discuss our findings below.

\subsection{Managerial mindset of parent company and impact of strategic miscalculations}

The centralization of $\mathrm{R} \& \mathrm{D}$ in Fiat is similar to that in other car companies such as GM and Chrysler, and other companies that produce complex products based on global value chains - (see e.g. the discussion in Dodgson et al., 2008: 186-205). The many stages involved in the production and technical performance of complex products renders management of dispersed activity quite challenging and decision making over production and R\&D usually resides in the parent firm. Thus the evolutions in even very successful companies (e.g. Toyota) may not reach all of their geographically dispersed competence creating subsidiaries.

In Fiat, we found evidence of global integration accompanied by control of technology remaining with the central Fiat $R \& D$ unit, and assignment of roles to avoid non-duplication although at the expense of intra-company competition. While Fiat has been very successful in effecting information flows among subsidiaries and between HQ and subsidiaries through the use of ICT and exchanges of engineers, it was reluctant to make subsidiaries autonomous even when they were mandated to make improvements to respond to local consumer needs. An example of this was the air-conditioning problem which ultimately may have cost Fiat its Indian market share.

What is the explanation for the managerial mind-set of retaining control? It might lie in the nature of the subsidiary. The R\&D subsidiaries in Turkey and India were JVs and there perhaps was reluctance to share technologies between the partner firms. However, the 
Brazilian subsidiary was wholly owned and apparently trusted by Fiat HQ, but our interviews revealed that it took some eight years after P178 before the subsidiary was able to act autonomously. For instance, in 1996-2002 FIASA filed very few patents, which suggests considerable 'organizational inertia' (Criscuolo and Narula, 2007) and which prevented the development of a multi-hub structure of R\&D.

The success of centralized R\&D strategies depends critically on the soundness of the product market strategies chosen by the parent. As noted in Section 4, Fiat's 'global car' strategy owed much to Fiat's success in MERCOSUR, and features of the Fiat Palio that had proven successful in the Latin American market. However, what was right for the Latin America was not successful for the Turkish and Indian markets. This suggests insufficient local market information informing the choice of model and, more importantly, lack of a contingency plan when the Palio proved unsuccessful. This miscalculation had profound implications for subsidiary performance and might also have influenced the evolution of competence creation roles.

\subsection{Product market performance and subsidiary capability}

Table 4 showed that Fiat Brazil was the most successful R\&D subsidiary on several performance measures (head count, sales, collaborative patents) and Fiat's biggest market share was in the Brazilian market. Many scholars see this as reflecting the superior capabilities of the Brazilian subsidiary which led to its emergence as a strategic leader among the Fiat subsidiaries in emerging markets. Although, Quadros and Consoni (2009) argue that the combination of local capability in product development and attainment of sales leadership in the Brazilian automobile market contributed to Fiat's increasing technological activities in Brazil, Quadros and Queiroz (2001) suggest that the scale of operation was the main reason for the concentration of design and management competencies in Brazil. This suggests the existence of a virtuous circle in which sales leadership depends on scale which allows the development of specialization valuable to the whole MNE.

Our case study sheds light on what happens when sales projections are not realised and the virtuous circle between high sales growth, creation of specialised assets and development of trust and confidence in the subsidiary's capability is not developed. Sales that do not 
meet projections affect what subsidiaries can do and the complexity of their activities. This was explained to us by the Indian R\&D manager:

Lots of activities depend on how much budget is available. If we have sold sufficient number of cars here I could used the money on setting up the rig here and so on... (Brazil) produces 5000 cars a day. That is the difference, their profitability is huge. If the market requires a change I need it now can you give it? No... Profit is being made, that means a lot [for what we can do]. Latin America is the leading market for Fiat now. But if India, China and Russia are focused well, it is a huge market.

In turn the type of activity the subsidiary is allowed to undertake has a major effect on its ability to retain skilled engineers who want to work on technically demanding projects. The absorptive capacity of the R\&D subsidiary and its $R \& D$ capability depends on skilled engineers. The technological capability of the subsidiary is dependent on its product market performance an area where the direction was set by Fiat's HQ. Tofaş may have avoided a downward spiral due in part to its independence from Fiat for funding for R\&D. Its decision to offer R\&D services to Peugeot and Citroen is significant and shows that the subsidiary wants to expand in order to retain its skilled employees.

Comparing among subsidiaries it is difficult to pinpoint why Fiat Brazil was so much more competitive (shown by Fiat's market share) than the Turkish and Indian subsidiaries. Dunford (2009) points out the Latin American market was the most protected of Fiat's markets outside Europe and was not subject to the same pressures of competition as the liberalizing Turkish and Indian markets. This would explain why, with substantially the same product and technology, Fiat was more successful in Brazil.

\subsection{Embeddedness and mode of entry}

There is an interesting dilemma highlighted by the case study of Fiat related to the complicated relationship between local and internal embeddedness. Similar to other firms confronted with the complexities of operating in emerging economy conditions, Fiat sought to minimize operational risks by opting for a JV strategy in production and R\&D with local 
partners in Turkey and India. ${ }^{14}$ These local partners were highly embedded in their environmental contexts and the parent saw centrality and collaboration in local networks as favouring increased R\&D investment in those locations. It is unclear why, despite evidence of high technological capability (large number of national patent filings), Tofaş achieved only low levels of internal embeddedness. For example, we found no evidence of coinvention, establishment of a design center or work on new technologies and although Tofaş mentioned technology contributions to other MNE affiliates these were not mentioned by the parent firm.

The sensitive nature of why one subsidiary was more embedded internally than another, made it difficult to address this directly in interviews with either Fiat management or Tofaş. However, the literature on mode of entry offers some explanations. Deloitte (2010) estimates that most research JVs terminate earlier than expected and that the median duration of a JV is three years. Further, JVs are often set up with potential competitors and their management in the context of R\&D may be impossible without finite and clear expectations about the research outputs. It is also clear that greenfield managers are more likely to be treated as 'insiders' and JV mangers are more likely to be treated as 'outsiders' as the latter do not have the same degree of socialization within the MNE network. For both these reasons, we can conjecture that the JV nature of the Turkish subsidiary may have made Tofaş less relevant as a candidate for intra-MNE strategic collaboration. Tofaş' decision to keep patents on all R\&D work done for Fiat is also consistent with such reasoning.

\section{Conclusions}

Our case study shows that although Fiat has a large number of production subsidiaries in emerging markets, only three of its emerging market subsidiaries undertook any R\&D and only one of them (in Brazil) came close to possessing the characteristics of a competencecreating subsidiary, i.e. becoming a strategic leader with more product development responsibilities and exhibiting dual embeddedness. This suggests that rise of competencecreating subsidiaries in emerging markets is difficult. Furthermore, technology creation

\footnotetext{
${ }^{14}$ Raff et al., (2006) show that firms that have more profitable assets will always choose greenfield investment over JV. This suggests that entering a JV in two emerging economies was a reflection of Fiat's poor competitive position. Similarly and as noted earlier Cantwell and Mudambi (2011) suggest that laggard firms will find it more difficult to attract good quality partners to tap into local advantages.
} 
requires active scanning and identification of new sources of ideas -- a managerial capability that did not emerge from our interviews with CRF- the parent R\&D lab. As a consequence of centralised control, we found that subsidiary role enhancement in Brazil was driven largely by parent firm investments.

The success of the Brazilian subsidiary raises the question of why the Indian and Turkish subsidiaries did not develop into competence-creating subsidairies. The failure of competence-creation in subsidiaries in emerging markets has been rarely addressed in the literature, but our embedded case study design allows conjectures: we can suggest two explanations.

First, we found that the evolution of subsidiaries' R\&D activities was determined by the extent of success in achieving good product market performance rather than possession of technological capability alone. Thus local competition and the company's overall product market strategy were crucial determinants of an increased subsidiary role. Market performance is constrained by the success of the HQ product market strategy. Here, decisions about what models to sell in which markets were made by Fiat HQ. Poor strategy formulation at headquarters as well as poor execution of strategy led to poor competitive outcomes at subsidiary level.

The case of the Turkish subsidiary is very puzzling since it was well established and showed high levels of external embeddedness and technological capability although low levels of internal embeddedness. Thus our second conjecture is that R\&D subsidiaries set up as part of JVs are less likely to become embedded in the MNE's internal network and being considered capable of executing a competence creating mandate.

We hope that future empirical work on competence creating subsidiaries will test these arguments more rigorously focusing on the selection issues implicit in the choice of competence-creating subsidiaries. Our case study shows that technological capability and local environmental factors are not the only factors influencing a competence creation mandate- the mode of entry and the effectiveness of HQ strategy may also influence a subsidiary's competence-creation role. 


\section{References}

Ambos, B., 2005. Foreign direct investment in industrial research and development: a study of German MNCs. Research Policy. 34 (4), 395-410.

Andersson, Forsgrem Holm, 2002, The strategic impact of external networks: Subsidiary performance and competence development in the multinational corporation. Strategic management Journal, 23.

Andersson, U., Forsgren, M., Holm, U., 2007. Balancing subsidiary influence in the federative MNC: a business network view. J. Int. Business Studies. 38, 802-18.

Balcet, G., Enrietti A., 1999. La mondialisation ciblée de fiat et la filière automobile italienne: 1 Impact dans le Mercosur (Globalization of Fiat Auto and Italian automotive industry: its impact on Mercosur countries). Proceedings of Gerpisa Conference. 25.

Bartlett, C. A., Ghoshal, S., 1986. 'Tap your subsidiaries for global reach'. Harvard Business Review, 64, 87-94.

Bartlett, C. A., Ghoshal, S., 1991. Managing Across Borders: The Transnational Solution, Boston, Harvard Business School Press.

Birkinshaw, J., Hood, N., 1998. Multinational subsidiary evolution: capability and charter change in foreign-owned subsidiary companies. Academy of Management Review. 23 (4), 773-795.

Cantwell, J., 1995. The globalisation of technology: what remains of the product cycle model? Cambridge Journal of Economics. 19 (1), 155-174.

Cantwell, J., Mudambi, R., 2005. MNE competence-creating subsidiary mandates. Strategic Management J. 26, 1109-1128.

Cantwell, J. and Mudambi, R., 2011. Physical attraction and the geography of knowledge sourcing in multinational enterprises. Global Strategy Journal, 1, 206-232.

Cassiolato, J., Lastres, H., Szafiro, M., Vargas, M., 2001. Local systems of innovation in Brazil, development and transnational corporations: A preliminary assessment based on empirical results of a research project. Conference paper for the DRUID Nelson-Winter conference, Elsinore, Denmark.

Ciravegna, L., 2003. Global and regional integration of production in the Mercosur's automotive value chains: The case of Fiat. Working paper for the EADI workshop clusters and value chains in the north and in the third world. Universitá del Piemonte Orientale, Novara.

Ciravegna, L. 2005. Declino o trasformazione? Il ruolo delle scelte strategiche nell industria dell auto (Decline or transformation? The role of strategic choices in the car industry). SEMEQ Department, Faculty of Economics, University of Eastern Piedmont, Working Papers 108. 
Criscuolo, P., Narula, R., 2007. Using multi-hub structures for international R\&D: organisational inertia and the challenges of implementation. Management Int. Review. 47 (5), 639-660.

Deloitte, 2010. A study of Joint Ventures- The challenging world of alliances. Luxembourg - China ${ }^{\text {ees }}$ gateway to Europe. Deloitte, France.

Dicken, P., 2003. Global Shift: Reshaping the Global Economic Map in the 21st Century, Sage Publications Ltd.

Dodgson, M., Gann, D., Salter, A., 2008. The Management of Technological Innovation: Strategy and Practice, Oxford University Press.

Dunning, J.H., 1981. The Eclectic (OLI) Paradigm of International Production: Past, Present and Future. Int. J. the Economics of Business. 8 (2), 173-190.

Dunford, M., 2009. Globalization failures in a neo-liberal world: the case of Fiat Auto in the 1990s. Geoforum, 40 (2), 145-157.

Economist, 2008. Rebirth of a car maker, http://www.economist.com/node/11090197.

Fiat Group Annual Report 1999, http://www.fiatspa.com/en-

US/investor_relations/financial_reports/FiatDocuments/Bilanci/1999/BIL1999_Rel_Gest_I NG.pdf.

Fiat Group Annual Report 2011, http://www.fiatspa.com/enUS/investor_relations/financial_reports/FiatDocuments/Bilanci/2011/Fiat_AnnualReport_2 011_ENG.pdf.

Figueiredo, N.P., 2011. The role of dual embeddedness in the innovative performance of MNE subsidiaries: evidence from Brazil. J. Management Studies. 48 (2), 417-440.

Gerybadze, A., Reger, G. 1999. Globalization of R\&D: recent changes in the management of innovation in transnational corporations, Research Policy, 28, 251-274.

Hedlund, G., 1986. The hypermodern MNC: A heterarchy? Human Resource Management. 25, 9-36.

Hood, N., Young, S., 1982. US multinational R\&D. Multinational Business. 2, 10-23.

Johanson, J., Vahlne, J-E, 1977. The internationalization process of the firm- a model of knowledge development and increasing foreign market commitments. J. Int. Business Studies. 8(1), 23-32.

Kogut, B., Zander, U., 1992. Knowledge of the firm, combinative capabilities, and the replication of technology. Organization Science. 3 (2), 383-397.

Kogut, B., Zander, U., 2003. A memoir and reflection: knowledge and an evolutionary theory of the multinational firm 10 years later. J. Int. Business Studies. 34 (6), 505-515. 
Kuemmerle, W., 1997. Building effective R\&D capabilities abroad. Harvard Business Review. March-April, 61-70.

Lahiri, N., 2010. Geographic distribution of R\&D activity: How does it affect innovation quality? The Academy of Management Journal 53, 1194-1209.

Manning, S., Hutzschenreuter, T., Strathmann, A., 2009. Emerging capabilities or continuous challenge? Managing interfaces in shifting global engineering networks. Duke CIBER Short Working Paper.

Meyer, K.E., Mudambi, R., Narula, R, 2011. Multinational enterprises and local contexts: the opportunities and challenges of multiple embeddedness. J. Management Studies. 48 (2), 235-252.

Mishra, A.K., Surendar, T., 2010. Will Tata Motors and Fiat ride out the jinx? Forbes India. http://forbesindia.com/printcontent/19722.

Narula, R., Dunning, J.H., 2010. Multinational enterprises, development and globalisation: Some clarifications and a research agenda. Oxford Development Studies. 38, (3), 263-287.

Patel, P. 2011. Location of Innovative Activities of EU Large Firms. SPRU Electronic Working Paper. 190.

Patel, P., Pavitt, K., 1991. Large firms in the production of the worlds technology- an important case of non-globalization. J. Int. Business Studies. 22 (1), 1-21.

Phene, A., Almeida, P., 2008. Innovation in multinational subsidiaries: The role of knowledge assimilation and subsidiary capabilities. J. Int. Business Studies. 39, 901-919.

Pearce, R. D. 1994. The internationalisation of research and development by multinational enterprises and the transfer sciences. Empirica, 21 (3), 297-311.

Quadros, R., Queiroz, S., 2001. The implications of globalisation, for the distribution of design competences in the auto industry in Mercosur. Proceedings of Gerpisa. 32, 35-44.

Quadros, R., Consoni, F., 2009. Innovation capabilities in the Brazilian automobile industry: a study of vehicle assemblers' technological strategies and policy recommendations. Int. J. Technological Learning, Innovation and Development. 2, 53-75.

Queiroz, S., and Carvalho, R.Q., 1999. Recent developments in Brazilian auto vehicle and components trade: building the space of production in Mercosur. Proceedings of Gerpisa. $25,65-75$.

Rugman, A.M., Verbeke, A., Yuan, W., 2011. Re-conceptualizing Bartlett and Ghoshal's classification of national subsidiary roles in the multinational enterprise. Journal of Management Studies. 48 (2), 253-277.

Sturgeon, T., Memedovic, O., Van Biesebroeck, J., Gereffi, G., 2009. Globalization of the automotive industry main features and trends. Int. J. Technological Learning, Innovation and Development. 2 (1-2), 7-24. 
Uzzi B 1996, The source and consequences of embeddedness for the economic performance of organizations: The network effect. American Sociological Review 61.

Uzzi B 1997, Social structure and competition in interfirm networks. The paradox of embeddedness. Administrative Science Quarterly 42.

Vemon, R., 1966. International investments and international trade in the product cycle. Quarterly Journal of Economics. 80, 190-207.

Verspagen, B., Schoenmakers, V., 2004. The spatial dimension of patenting by multinational firms in Europe. Journal of Economic Geography, Oxford University Press. 4 (1), 23-42.

Yin, R.K., 2003. Case Study Research, Design and Methods, 3rd ed. Newbury Park, Sage. 


\section{Appendix 1: List of interviews conducted}

\begin{tabular}{|c|c|c|c|}
\hline Country & Interviewee Designation & Interview Date & Location \\
\hline & 1) Chief R\&D Engineer & 5 January 2009 & $\begin{array}{l}\text { Tofaş } \\
\text { Bursa/Turkey }\end{array}$ \\
\hline $\begin{array}{l}\text { ITALY: } \\
\text { Fiat }\end{array}$ & $\begin{array}{l}\text { 2) Quality and Relations } \\
\text { Director } \\
\text { 3) Alternative Fuels Engine } \\
\text { Director } \\
\text { 4) Group Materials Labs- New } \\
\text { Materials Scouting \& } \\
\text { Nanomaterials Department } \\
\text { Manager } \\
\text { 5) Quality System Manager }\end{array}$ & 14 December 2010 & $\begin{array}{l}\text { Centro Ricerche } \\
\text { Fiat (Fiat } \\
\text { Research Centre) } \\
\text { Turin/Italy }\end{array}$ \\
\hline \multirow{3}{*}{$\begin{array}{l}\text { TURKEY: } \\
\text { Tofaş }\end{array}$} & 6) Former R\&D Director & 20 January 2009 & $\begin{array}{l}\text { Platform R\&D } \\
\text { Bursa/Turkey }\end{array}$ \\
\hline & 7) $R \& D$ Director & 7 February 2009 & $\begin{array}{l}\text { Tofaş } \\
\text { Bursa/Turkey }\end{array}$ \\
\hline & $\begin{array}{l}\text { 8) Chief R\&D Engineer of } \\
\text { Mekatro Co. (Tofaş's } \\
\text { subsidiary) }\end{array}$ & $\begin{array}{l}13 \text { January } 2009 \text { (updated } \\
\text { 2012) }\end{array}$ & $\begin{array}{l}\text { Mekatro R\&D } \\
\text { Gebze/Turkey }\end{array}$ \\
\hline $\begin{array}{c}\text { INDIA: } \\
\text { Fiat India } \\
\text { Automobiles } \\
\text { Limited (FIAL) }\end{array}$ & $\begin{array}{l}\text { 9) Vice President of } \\
\text { Engineering \& Design (E\&D) }\end{array}$ & $\begin{array}{l}30 \text { August } \\
2011\end{array}$ & $\begin{array}{l}\text { FIAL } \\
\text { Pune/ India }\end{array}$ \\
\hline \multirow{4}{*}{$\begin{array}{l}\text { BRAZIL: } \\
\text { Fiat Automotive } \\
\text { South America } \\
\text { (FIASA) }\end{array}$} & $\begin{array}{l}\text { 10) Manager of Powertrain } \\
\text { Technologies Engines and } \\
\text { Transmissions }\end{array}$ & 3 May 2011 & $\begin{array}{l}\text { Belo Horizonte/ } \\
\text { Brazil }\end{array}$ \\
\hline & $\begin{array}{l}\text { 11) Director of Product } \\
\text { Engineering }\end{array}$ & 3 May 2011 & $\begin{array}{l}\text { Belo Horizonte/ } \\
\text { Brazil }\end{array}$ \\
\hline & $\begin{array}{l}\text { 12) Manager of Procurement } \\
\text { and Supplier Development } \\
\text { 13) Coordinator of Product } \\
\text { Engineering- Innovation and } \\
\text { Methodology }\end{array}$ & 01 July 2010 & $\begin{array}{l}\text { FIASA } \\
\text { Betim, Minas } \\
\text { Gerais/Brazil }\end{array}$ \\
\hline & $\begin{array}{l}\text { 14) Director of Insituto de } \\
\text { Competencias Empresariais } \\
\text { (ICE-Fiat) } \\
\text { 15) Manager of the Committee } \\
\text { for Innovation (FPT) of ICE- } \\
\text { Fiat }\end{array}$ & 01 July 2010 & $\begin{array}{l}\text { FIASA Betim, } \\
\text { Minas } \\
\text { Gerais/Brazil }\end{array}$ \\
\hline
\end{tabular}

